\title{
Kandungan nutrien kulit pisang kepok (Musa paradisiaca) yang difermentasi dengan cairan rumen kambing
}

\author{
Nutritive content of banana peel flour (Musa paradisiaca) fermented by goat rumen fluid \\ Maria Theresia Sa' ${ }^{1}$ Tri Anggarini Y. Foenay ${ }^{2}$, Theresia Nur Indah Koni ${ }^{*}$ \\ ${ }^{1}$ Program Studi Teknologi Pakan Ternak, Jurusan Peternakan, Politeknik Pertanian Negeri Kupang. Jl. Prof. Dr. \\ Herman Yohanes, Lasiana, Kelapa Lima, Kota Kupang 85011, NTT \\ ${ }^{2}$ Program Studi Produksi Ternak, Jurusan Peternakan, Politeknik Pertanian Negeri Kupang . Jl. Prof. Dr. Herman \\ Yohanes, Lasiana, Kelapa Lima, Kota Kupang 85011, NTT \\ *Email Koresponden: Indahkoni@gmail.com
}

\begin{tabular}{|c|c|}
\hline ARTICLE INFO & A B S T R A K \\
\hline $\begin{array}{l}\text { Received: } \\
27 \text { January } 2021\end{array}$ & \multirow{6}{*}{$\begin{array}{l}\text { Tujuan penelitian ini adalah untuk mengkaji perubahan nutrien tepung kulit } \\
\text { pisang kepok (Musa paradisiaca) yang difermentasi dengan cairan rumen kambing. } \\
\text { Rancangan penelitian yang digunakan adalah Rancangan Acak Lengkap (RAL) } \\
\text { dengan } 4 \text { perlakuan dan } 5 \text { ulangan. Keempat perlakuan yang diterapkan antara } \\
\text { lain P0: tepung kulit pisang kepok }+0 \% \text { cairan rumen kambing (kontrol), P1: } \\
\text { tepung kulit pisang kepok + } 30 \% \text { cairan rumen kambing, P2: tepung kulit pisang } \\
\text { kepok + } 40 \% \text { cairan rumen kambing, P3: tepung kulit pisang kepok + } 50 \% \text { cairan } \\
\text { rumen kambing. Proses fermentasi dilakukan selama } 7 \text { hari. Hasil penelitian ini } \\
\text { menunjukkan bahwa penggunaan cairan rumen kambing menyebabkan perubahan } \\
\text { (P<0,05) kandungan nutrien tepung kulit pisang kepok fermentasi. Penggunaan } \\
50 \% \text { cairan rumen kambing dapat meningkatkan kandungan lemak kasar dan } \\
\text { protein kasar, namun menurunkan kandungan bahan kering dan serat kasar } \\
\text { tepung kulit pisang kepok. }\end{array}$} \\
\hline $\begin{array}{l}\text { Accepted: } \\
24 \text { March } 2021\end{array}$ & \\
\hline $\begin{array}{l}\text { Published: } \\
31 \text { March } 2021\end{array}$ & \\
\hline $\begin{array}{l}\text { Kata kunci: } \\
\text { Cairan rumen }\end{array}$ & \\
\hline Kambing & \\
\hline $\begin{array}{l}\text { Kandungan nutrien } \\
\text { Kulit pisang }\end{array}$ & \\
\hline
\end{tabular}

\section{A B S T R A C T}

The purpose of this study was to determine the nutritional content of fermented Kepok banana peel flour (Musa paradisiaca L.) by goat rumen liquid. This study was designed using a completely randomized design (CRD) with 4 treatments and 5 replications. The four treatments were PO: Kepok banana peel flour $+0 \%$ goat rumen fluid (control), P1: Kepok banana peel flour + 30\% goat rumen fluid, P2: Kepok banana peel flour $+40 \%$ goat rumen fluid, P3: Kepok banana peel flour $+50 \%$ goat

Key words:

Rumen fluid

Goat rumen fluid. The fermentation process was carried out for 7 days. The results of this study showed that the use of goat rumen fluid changed $(P<0.05)$ the nutrient content of fermented Kepok banana peel flour. The use of 50\% goat rumen fluid increased Nutrient content Banana peels crude protein and crude fat content, however reduced the dry matter and crude fiber content of Kepok banana peel flour.

\section{PENDAHULUAN}

Rendahnya ketersediaan bahan pakan, meningkatnya kebutuhan pakan, serta persaingan dengan bahan pangan menjadi faketor yang menyebabkan peningkatan harga pakan. Upaya untuk menekan harga pakan, yaitu memanfaatkan bahan pakan lokal yang tersedia melimpah dan mudah diperoleh, seperti limbah kulit pisang.
Pisang merupakan jenis buah yang banyak terdapat di Indonesia dengan berbagai jenis, antara lain pisang ambon, pisang raja, pisang mas dan pisang kepok. Data Badan Pusat Statistik (BPS, 2018) menunjukkan produksi pisang di Provinsi Nusa Tenggara Timur (NTT) tahun 2018 mencapai 92.988 ton/tahun. Koni, Bale-Therik, \& Kale, (2013) ;Diarra, (2018) menyatakan bahwa kulit pisang mempunyai berat $25-40 \%$ dari 
berat buah pisang. Berdasarkan data ini maka diperkirakan sebanyak 23.247-37.195,2 ton/ tahun kulit pisang yang dihasilkan di Provinsi NTT.

Beberapa hasil penelitian melaporkan bahwa kulit pisang dapat dimanfaatkan hingga 3-20\% dalam pakan broiler (Widjastuti \& Hernawan, 2012; Koni, 2013; Farman et al., 2016), tetapi kadar serat kasar dan tanin yang tinggi menyebabkan terbatasnya pemanfaatan kulit pisang sebagai pakan monogastrik. Kadar serat kasar pada kulit pisang mencapai 18,01\% (Widjastuti \& Hernawan, 2012); 18.71\%(Koni, 2013), 36,7\% (Hudiansyah, Sunarti, \& Sukamto, 2015); 44,28\% (Mosa \& Khalil, 2015) dan kadar tanin 4,87\% (Hudiansyah et al., 2015).

Serat kasar dan tanin dapat direduksi melalui proses pengolahan secara biologi yang disebut dengan metode fermentasi. Hudiansyah et al., (2015) menyatakan kadar serat kasar pada kulit pisang sebesar $34,67 \%$ mengalami penurunan setelah dilakukan fermentasi menjadi 15,25\%. Ridla, Mullik, Prihantoro, \& Mulik (2016) menyatakan terjadi penurunan tanin sebesar 14,18\% pada Chromolena odorata setelah dilakukan ensilase selama 21 hari.

Proses fermentasi memerlukan sumber mikroorganisme sebagai pemecah komponen serat kasar, salah satunya menggunakan mikroorganisme yang berasal dari cairan rumen kambing. Pamungkas (2012) menyatakan bahwa sumber mikroorganisme dalam fermentasi dapat diperoleh dari cairan rumen kambing yang merupakan limbah rumah potong hewan. Tujuan penelitian ini untuk mengkaji perubahan nutrien kulit pisang yang difermentasi dengan cairan rumen kambing.

\section{MATERI DAN METODE}

Lokasi penelitian dilakukan di Laboratorium Nutrisi dan Pakan Ternak, Jurursan Peternakan Politeknik Pertanian Negeri Kupang.

\section{Materi Penelitian}

Penelitian fermentasi kulit pisang ini menggunakan cairan rumen kambing yang diambil dari Rumah Pemotongan Hewan (RPH). Kulit pisang kepok yang telah matang diambil dari tempat pengolahan pisang di kota Kupang.

\section{Metode Penelitian}

Tepung kulit pisang kepok difermentasi dengan cairan rumen pada kadar air 60\%. Penggunaan cairan rumen terdiri dari 4 perlakuan dan 5 ulangan. Adapun perlakuan yang diberikan yaitu P0: 0\%, P1: 30\%, P2: 40\% dan P3: 50\% dari bahan kering tepung kulit pisang. Tepung kulit pisang kemudian difermentasi secara anaerob selama 7 hari. Data yang diperoleh dianalisis ANOVA menggunakan Rancangan Acak Lengkap (RAL).

\section{Prosedur Penelitian}

Proses fermentasi merujuk pada penelitian Ermalia, Sjofjan, \& Djunaidi, (2016). Kulit pisang kepok yang digunakan adalah kulit yang telah matang dan berwarna kuning. Kulit pisang kepok dicuci dengan air bersih untuk mengeluarkan kotoran yang menempel pada permukaan kulit, kemudian diiris menggunakan pisau dengan ukuran kurang lebih 2-3 cm., selanjutnya dikeringkan dengan cara dijemur dibawah sinar matahari selama 2 hari hingga kering.

Kulit pisang yang telah kering kemudian digiling menggunakan roller mill dengan ukuran saringan $3 \mathrm{~mm}$. Tepung kulit pisang dicampur dengan cairan rumen kambing sesuai perlakuan hingga homogen, serta dimasukkan dalam toples kapasitas $1 \mathrm{~kg}$ sambil dipadatkan kemudian ditutup rapat untuk difermentasi. Fermentasi anaerob dilakukan selama tujuh hari. Setelah tujuah 7 hari kulit pisang fermentasi dikeluarkan dan ditimbang. Tepung kulit pisang dikeringkan dalam oven $60^{\circ} \mathrm{C}$, selama 48 jam.

Setelah 48 jam tepung kulit pisang terfermentasi dikeluarkan dan didinginkan, dan dilakukan proses analisis proksimat untuk mengetahui kadar bahan kering, kadar lemak kasar, kadar serat kasar dan kadar protein kasar sesuai metode AOAC (2005).

\section{Parameter Penelitian}

Parameter yang diamati pada penelitian ini yaitu kandungan bahan kering, ; lemak kasar, serat kasar dan protein kasar yang ditentukan berdasarkan metode (AOAC, 2005).

\section{Analisis Data}

Data yang dihasilkan dianalisis menggunakan Analysis of Varians (ANOVA) dan 
dilanjutkan dengan Duncan's Multiple Range Test (DMRT) (Gasperz, 2006).

\section{HASIL DAN PEMBAHASAN}

Rata-rata kandungan bahan kering, lemak kasar dan serat kasar kulit pisang kepok setelah difermentasi dengan cairan rumen kambing yang disajikan pada Tabel 1.

\section{Bahan Kering Tepung Kulit pisang Kepok Fermentasi}

Level pemberian cairan rumen kambing berpengaruh sangat nyata $(\mathrm{P}<0,01)$ terhadap kadar bahan kering tepung kulit pisang. Aktivitas mikroorganisme selama proses fermentasi yang menguraikan bahan organik dan menghasilkan produk berupa air diduga menjadi penyebab perubahan kadar bahan kering kulit pisang. Aro (2010) menjelaskan pada saat proses fermentasi, mikroorganisme memanfaatkan karbohidrat sebagai sumber energi yang dapat menghasilkan molekul air $\left(\mathrm{H}_{2} \mathrm{O}\right)$ dan karbondioksida. Sebagian besar air akan tertinggal dalam produk. Air yang tertinggal dalam produk tersebut yang akan menyebabkan kadar air substrat menjadi tinggi dan bahan kering menjadi rendah. Hasil penelitian ini sejalan dengan penelitian Nalar, Irawan, Rahmatullah, Muhammad, \& Kurniawan, (2014) pada dedak padi hasil fermentasi dengan cairan rumen menghasilkan bahan kering yang rendah.

Kadar bahan kering pada perlakuan P0

Tabel 1. Rata-rata bahan kering, lemak kasar, dan serat kasar tepung kulit pisang kepok fermentasi dengan cairan rumen kambing

\begin{tabular}{lccc}
\hline & \multicolumn{3}{c}{ Paramenter } \\
\cline { 2 - 4 } Perlakuan & $\begin{array}{c}\text { Bahan } \\
\text { kering }\end{array}$ & $\begin{array}{c}\text { Lemak } \\
\text { Kasar }\end{array}$ & Serat kasar \\
\cline { 2 - 4 } & $(\%)$ & $(\%)$ & $(\%)$ \\
\hline P0 & $74,50^{\mathrm{a}}$ & $6,89^{\mathrm{b}}$ & $13,21^{\mathrm{a}}$ \\
P1 & $71,74^{\mathrm{a}}$ & $7,23^{\mathrm{b}}$ & $12,20^{\mathrm{b}}$ \\
P2 & $61,53^{\mathrm{b}}$ & $6,97^{\mathrm{b}}$ & $12,38^{\mathrm{b}}$ \\
P3 & $64,48^{\mathrm{b}}$ & $8,70^{\mathrm{a}}$ & $12,08^{\mathrm{b}}$ \\
\hline SEM & 1,49 & 0,19 & 0,13 \\
\hline $\mathrm{p}$ & 0,001 & 0,001 & 0,002 \\
\hline
\end{tabular}

SEM: Standar error of mean, p: probability, a,b, superskrip yang berbeda pada kolom yang sama menunjukkan berbeda nyata $(\mathrm{P}<0,05)$. berbeda nyata $(\mathrm{P}<0,05)$ dengan perlakuan $\mathrm{P} 2$ dan P3, tetapi tidak berbeda nyata $(P>0,05)$ dengan perlakuan P1. Peningkatan kadar air terjadi disebabkan adanya proses fermentasi oleh mikroorganisme pada cairan rumen yang menghasilkan air. Menurut Cahyadi, (2018) mikroorganisme menggunakan zat-zat nutrien dalam substrat sebagai sumber energi dan proses metabolism menghasilkan molekul air.

\section{Lemak Kasar Tepung Kulit pisang Kepok Fermentasi}

Level cairan rumen kambing berpengaruh sangatnyata $(\mathrm{P}<0,01)$ terhadaplemakkasartepung kulit pisang kepok fermentasi. Hal ini disebabkan bertambahnya jumlah mikroorganisme seiring dengan peningkatan level cairan rumen kambing, kadar lemak ini diduga berasal dari akumulasi lemak pada tubuh mikroorganisme. Suadnyana, Cakra, \& Wirawan (2017) menyatakan bahwa tubuh bakteri terdiri dari 6-11\% lemak.

Perlakuan P3 mempunyai kadar lemak kasar lebih tinggi $(\mathrm{P}<0,05)$ dibandingkan perlakuan P0, P1 dan P2, sedangkan antar perlakuan P0, P1 dan P2 mempunyai kadar lemak kasar yang berbeda tidak nyata $(\mathrm{P}>0,05)$. Hal ini disebabkan mikroorganisme pada P3 kemungkinan berkembang secara optimum sesuai dengan ketersediaan nutrien pada kulit pisang. Mikroorganime memanfaatkan nutrien pada kulit pisang untuk membentuk lemak tubuh, sehingga kadar lemak pada substrat semakin tinggi. Atika, Liman, \& Sutrisna, (2015) menyatakan mikroorganisme pada ensilase membentuk asam lemak sehingga kadar lemak makin meningkat. Peningkatan kadar lemak kasar sebesar 54,78\% terjadi pada putak yang difermentasi dengan cairan rumen kambing selama 21 hari (Umbu, Hilakore, \& Amalo, 2020).-

\section{Serat Kasar Tepung Kulit pisang Kepok Fermentasi}

Hasil analisis varians menunjukkan penggunaan level cairan rumen kambing berpengaruh sangat nyata $(\mathrm{P}<0,01)$ terhadap kadar serat kasar kulit pisang kepok. Terjadi penurunan kadar kadar serat kasar setelah pemberian cairan rumen kambing pada proses fermentasi kulit pisang kepok. Penurunan kadar serat kasar ini kemungkinan terjadi karena dalam cairan rumen kambing ada mikroorganisme 
yang menghasilkan enzim selulase yang dapat mendegradasi komponen serat. Bakteri selulolitik dalam cairan rumen kambing seperti Bacillus sp. dan Streptococcus sp. (Oyeleke \& Okusanmi, 2008). Bakteri yang paling banyak ditemukan untuk degradasi serat di dalam rumen Fibrobacter succinogenes, Ruminococcus albus, dan Ruminococcus flavefaciens (Abubakr, Alimon, Yaakub, Abdullah, \& Ivan, 2014). Penurunan serat kasar juga terjadi pada dedak padi yang difermentasi dengan cairan rumen kambing (Nalar et al., 2014). Selanjutnya Andriani \& Pratiwy (2020) menyatakan bahwa cairan rumen mengandung mikroorganisme yang menghasilkan enzim selulase dan xylanase.

Perlakuan P0 memiliki kadar serat kasar yang lebih tinggi $(\mathrm{P}<0,05)$ daripada perlakuan $\mathrm{P} 1$, P2, dan P3. Kadar serat kasar antar perlakuan P1, P2 dan P3 berbeda tidak nyata $(P>0,05)$. Terlihat bahwa penggunaan cairan rumen menyebabkan penurunan serat kasar kulit pisang, hal ini kemungkinan karena di dalam cairan rumen kambing ada mikroorganisme pendegradasi serat kasar. Terjadi penurunan serat kasar disebabkan oleh mikroba yang mendegradasi serat kasar karena adanya enzim selulase (Hernawati et al., 2010). Penurunan serat kasar juga terjadi pada dedak padi yang difermentasi dengan $30 \%$ cairan rumen kambing, disebabkan oleh mikroba anaerob dalam cairan rumen kambing yang mampu menghasilkan enzim selulase untuk merombak serat kasar (Ermalia et al., 2016). Umbu et al. (2020) melaporkan terjadi penurunan serat pada putak yang difermentasi dengan cairan rumen kambing yaitu 5,03\% menjadi 4,53\% setelah difermentasi selama tujuh hari.

\section{Protein Kasar Tepung Kulit pisang Kepok Fermentasi}

Protein kasar merupakan senyawa organik kompleks yang mempunyai berat molekul tinggi seperti karbohidrat dan lipida. Data pengaruh perlakuan terhadap kadar protein kasar tepung kulit pisang fermentasi disajikan pada Gambar 1.

Hasil analisis varians menunjukkan bahwa level cairan rumen kambing berpengaruh sangat nyata $(\mathrm{P}<0,01)$ terhadap kadar protein kasar tepung kulit pisang kepok fermentasi. Semakin tinggi kadar cairan rumen kambing yang digunakan semakin tinggi kadar protein kasar. Hal ini diduga karena pertumbuhan mikroorganisme menyumbangkan protein mikrobia sehingga kadar protein kulit pisang meningkat. Nalar et al., (2014) melaporkan penggunaan 25\% cairan rumen dalam dedak padi fermentasi meningkatkan protein kasar 14,17\% - 14,39\%.

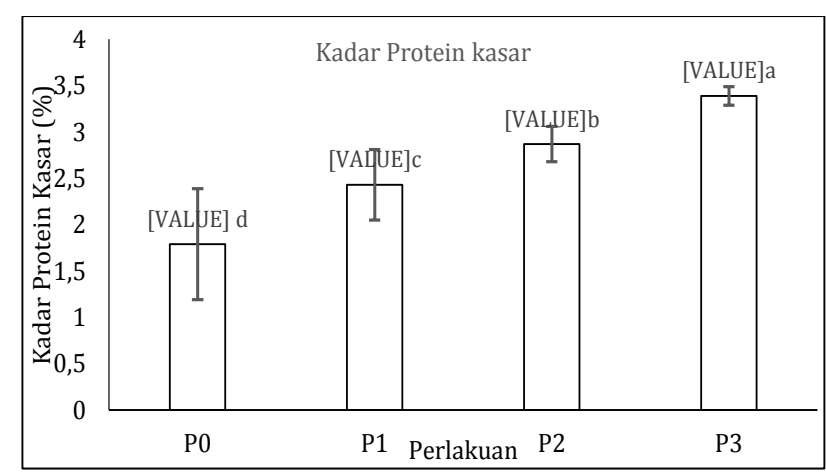

Gambar 1. Pengaruh level cairan rumen terhadap kadar protein kasar tepung kulit pisang kepok. Huruf yang berbeda pada kolom menunjukkan perbedaan yang nyata $(\mathrm{P}<0,05)$.

Kandungan protein kasar perlakuan P0 tidak berbeda nyata $(P>0,05)$ dengan perlakuan $P 1$, tetapi berbeda nyata $(\mathrm{P}<0,05)$ dengan perlakuan P2 dan P3. Adapun perlakuan P1 berbeda nyata $(\mathrm{P}<0,05)$ dengan perlakuan $\mathrm{P} 2$ dan $\mathrm{P} 3$. Perlakuan P2 berbeda nyata $(\mathrm{P}<0,05)$ dengan perlakuan P3 dan terlihat bahwa kandungan protein kasar perlakuan P3 (PK 3,39\%) lebih tinggi $(\mathrm{P}<0,05)$ dari semua perlakuan. Hal ini diduga semakin meningkat penambahan cairan rumen kambing maka semakin tinggi penambahan protein mikrobia dari bakteri yang bekerja pada proses fermentasi tersebut. Agustono, Herviana, \& Nurhajati (2011) menjelaskan salah satu enzim yang dihasilkan selama proses fermentasi adalah enzim protease yang mampu memecah protein menjadi polipeptida sederhana serta dipecah menjadi asam amino sehingga asam amino dapat dimanfaatkan mikroba untuk memperbanyak diri. Sel mikroorganisme pada proses fermentasi dapat meningkatkan protein kasar, karena mikroba juga merupakan sumber protein sel tunggal (Bachruddin, 2014). Penggunaan cairan rumen kambing juga dapat meningkatkan kadar protein kasar pada putak sebesar $23,80 \%$ setelah fermentasi selama tujuh hari (Umbu et al., 2020).

\section{KESIMPULAN}

Penggunaan cairan rumen kambing memberikan pengaruh terhadap kadar bahan kering, lemak kasar, serat kasar dan protein kasar tepung kulit pisang kepok hasil fermentasi. Penggunaan $50 \%$ cairan rumen kambing dapat menurunkan kadar bahan kering dan serat kasar, namun meningkatkan kadar lemak kasar dan protein kasar tepung kulit pisang kapok. 


\section{DAFTAR PUSTAKA}

Abubakr, A., Alimon, A. R., Yaakub, H., Abdullah, N., \& Ivan, M. (2014). Effect of feeding palm oil by-products based diets on total bacteria, cellulolytic bacteria and methanogenic archaea in the rumen of goats. PLoS ONE, 9(4), 1-6. doi:10.1371/journal. pone.0095713

Agustono, Herviana, W., \& Nurhajati, T. (2011). Kandungan protein kasar dan serat kasar kulit pisang kepok (Musa paradisiaca yang difermentasi dengan Trichoderma viride sebagai bahan pakan alternatif pada formulasi pakan ikan mas (Cyprinus carpio). Jurnal Kelautan, 4(1), 53-59.

Andriani, Y., \& Pratiwy, F. M. (2020). Isolation and identification of rumen microbes and rumen fluid enzymes to use as the bio-degradator feed in aquaculture. International Journal of Fisheries and Aquatic Studies, 8(4), 61-64.

AOAC (Association of Official Analytical Chemists). (2005). Official Methods of Analysis of the Association of Official Analytical Chemists (18th ed.). Washington, DC.: Association of Official Analytical Chemist.

Aro, S. (2010). Improvement in the nutritive quality of cassava and its by-products through microbial fermentation. African Journal of Biotechnology, 7(25), 4789-4797.

Atika, T., Liman, \& Sutrisna, R. (2015). Pengaruh penambahan tepung gaplek dengan tingkat berbeda terhadap kandungan nutrisi silase limbah sayuran. Jurnal Ilmiah Peternakan Terpadu, 3(3), 110-115.

Bachruddin, Z. (2014). Teknologi Fermentasi pada Industri Peternakan. Yogyakarta: Gadjah Mada University Press.

BPS. (2018). Statistik Pertanian. Kupang: Badan Pusat Statistik Provinsi NTT. Retrieved February 10, 2019, from https://ntt.bps. go.id/dynamictable/2018/02/05/566/ produksi-pisang-menurut-kabupatenkota-di - provins i - nusa-tenggaratimur-2011-2017.html

Cahyadi, W. (2018). Fermentasi Pangan (ED I). Bandung: Manggu makmur Tanjung Lestari.

Diarra, S. S. (2018). Peel meals as feed ingredients in poultry diets: Chemical composition, dietary recommendations and prospects. Journal of Animal Physiology and Animal Nutrition, 102(5), 1284-1295. doi:10.1111/ jpn.12954

Ermalia, A. A. U., Sjofjan, O., \& Djunaidi, I. H. (2016). Evaluation Nutritients Of Rice Bran Second Quality Fermented Using Rumen Fluid. Buletin Peternakan, 40(2), 113-123. doi:10.21059/buletinpeternak.v40i2
Farman, A. S., Wagan, R., Bhutto, Z. A., Tareen, M. H., Arain, M. A., Saeed, M., \& Soomro, R. N. (2016). Effct of orange and banana peel on the growth performnce of brioler. Advances in Animal and Veterinary Sciences, 4(7), 376-380. doi:10.14737/journal. aavs/2016/4.7.376.380

Gasperz, V.(2006). Teknik analisa dalam penelitian percobaan (Edisi III). Bandung: Tarsito.

Hernawati, T., Lamid, M., Hermadi, H. A., \& Warsito, S. H. (2010). Bakteri Seluloltik untuk Meningkatkan Kualitas Pakan Komplit Berbasis Limbah Pertanian. Veterinaria Medika, 3(3), 205-208.

Hudiansyah, P., Sunarti, D., \& Sukamto, B. (2015). Pengaruh penggunaan kulit pisang terfermentasi dalam ransum terhadap ketersediaan energi ayam broiler. Agromedia, 33(2), 1-9. doi:10.47728/ ag.v33i2.109

Koni, T. N. I. (2013). Pengaruh pemanfaatan kulit pisang yang difermentasi terhadap karkas broiler. Jurnal Ilmu Ternak Dan Veteriner, 18(2), 153-157. doi:10.14334/ jitv.v18i2.315

Koni, T. N. I., Bale-Therik, J., \& Kale, P. R. (2013). Pemanfaatan kulit pisang hasil fermentasi rhyzopus oligosporus dalam ransum terhadap pertumbuhan ayam pedaging. Jurnal Veteriner, 14(3), 365-370.

Manorek, J. M., Wolayan, F. R., Untu, I. M., \& Liwe, H. (2018). Biokonversi kulit pisang raja (Musa paradisiaca) dengan Rhizopus oligosphorus terhadap perubahan kandungan abu, serat kasar dan lemak kasar. Zootec, 38(1), 6676. doi:10.35792/zot.38.1.2018.17711

Mosa, Z. M., \& Khalil, A. F. (2015). The effect of banana peels supplemented diet on acute liver failure rats. Annals of Agricultural Sciences, 60(2), 373-379. doi:10.1016/j. aoas.2015.11.003

Nalar, H. P., Irawan, B., Rahmatullah, S. N., Muhammad, N., \& Kurniawan, A. K. (2014). Pemanfaatan cairan rumen dalam proses fermentasi sebagai upaya peningkatan kualitas nutrisi dedak padi untuk pakan ternak. In Seminar Nasional "Inovasi Teknologi Pertanian Spesifik Lokasi”, (pp. 563-568). Banjarbaru.

Oyeleke, S. B., \& Okusanmi, T. A. (2008). Isolation and characterization of cellulose hydrolysing microorganism from the rumen of ruminants. African Journal of Biotechnology, 7(10), 1503-1504. doi:10.4314/ajb.v7i10.58700

Pamungkas, W. (2012). Penggunaan Enzim Cairan Rumen Sebagai Alternatif Untuk Mendukung Pemanfaatan Bahan Baku 
Pakan Ikan Lokal. Media Akuakultur, 7(1), 32-38. doi:10.15578/ma.7.1.2012.32-38

Ridla, M., Mullik, Y. M., Prihantoro, I., \& Mulik, M. . (2016). Penurunan total tanin silase semak bunga putih (Chromolaena odorata) dengan aditif tepung Putak (Coryphaelata robx) dan isi rumen sapi. Buletin Peternakan, 40(3), 165-169. doi:10.21059/buletinpeternak. v40i3.12838

Suadnyana, I. M., Cakra, I. G. L. O., \& Wirawan, I. W. (2017). Kualitas fisik dan kimia silase jerami padi yang dibuat dengan penambahan cairan rumen sapi Bali. E-Jurnal FAPET UNUD, 5(1), 181-188.

Umbu, C. J. T., Hilakore, M. A., \& Amalo, D. (2020). Pengaruh Lama Fermentasi Dengan Cairan Rumen Kambing Terhadap Perubahan Kualitas putak. Jurnal Peternakan Lahan Kering, 2(3), 1022-1028.
Unni, K. N., Priji, P., Sajith, S., Faisal, P.A., \& Benjamin, S. (2016). Pseudomonas aeruginosa strain BUP2, a novel bacterium inhabiting the rumen of Malabari goat, produces an efficient lipase. Biologia (Poland), 71(4), 378-387. doi:10.1515/biolog-2016-0057

Widjastuti, T., \& Hernawan, E. (2012). Utilizing of banana peel (Musa sapientum) in the ration and its influence on final body weight, percentage of carcass and abdominal fat on broiler. Lucrări Ştiinţifice - Seria Zootehnie, 57, 104-109. 